\title{
Pre-dosing antibody levels and efficacy of thrombolytic drugs containing streptokinase
}

\author{
J D Gemmill, K J Hogg, F G Dunn, A P Rae, W S Hillis
}

\begin{abstract}
Objective-To evaluate the influence of pretreatment streptokinase resistance titre and the concentration of IgG antibodies to streptokinase on the efficacy of thrombolytic drugs containing streptokinase in restoring coronary patency in acute myocardial infarction.

Design-Comparative observational study. Setting-City general hospital.

Patients-One hundred and twenty four previously unexposed patients presenting within six hours of onset of acute myocardial infarction.

Interventions-Streptokinase, $1.5 \mathrm{MIU}$ as intravenous infusion over 60 minutes (60 patients), or anistreplase, 30 units as intravenous injection over five minutes (64 patients).
\end{abstract}

Main outcome measures-Pretreatment streptokinase resistance titre and concentration of IgG antibodies to streptokinase were measured in 96 and 124 patients respectively and coronary patency assessed angiographically at 90 minutes and 24 hours.

Results-Pretreatment streptokinase resistance titre and concentrations of IgG antibodies to streptokinase were low and skewed towards higher values. Those patients with coronary occlusion at 24 hours had a significantly higher median streptokinase resistance titre $\left(\begin{array}{llll}100 & v & 50\end{array}\right.$ streptokinase IU $\mathrm{ml}^{-1}, \mathbf{P}=\mathbf{0 . 0 2}$ ). There were trends towards a higher streptokinase resistance titre in those patients with coronary occlusion at 90 minutes (50 $v 20$ streptokinase $\mathrm{IU} \mathrm{ml} \mathrm{ml}^{-1}, P=0.06$ ) and higher concentrations of IgG antibodies to streptokinase in those with coronary occlusion at both 90 minutes and 24 hours (1.53 v 0.925, $P=0.03 ; 1.65 v 1.04 \mu \mathrm{g}$ streptokinase binding $\mathrm{ml}^{-1}, \quad P=0.06$ ). Coronary patency rates were similar in the two treatment groups.

Conclusions-In the range measured in previously unexposed patients the streptokinase resistance titre has a small, but significant, negative influence on the efficacy of streptokinase and anistreplase. This effect should be considered if retreatment with streptokinase or anistreplase is proposed.

(Br Heart $\mathcal{f} 1994 ; 72: 222-225)$

Thrombolytic agents are the standard treatment for acute myocardial infarction. Their efficacy for this indication is well documented in terms of achieving coronary patency, ${ }^{1-3}$ preserving left ventricular function, ${ }^{45}$ and improving survival rates. ${ }^{67}$ Streptokinase is of proved efficacy for first treatment ${ }^{89}$ and anistreplase has the advantage of allowing easy administration outside the hospital by bolus dosing. ${ }^{10}$ The thrombolytic effects of these two drugs are mediated by the activation of plasminogen by a streptokinase-activator complex, in the case of streptokinase after combining streptokinase with circulating plas$\min$ (ogen), ${ }^{11}$ and of anistreplase after the rate limiting hydrolysis of the compound in the circulation liberating streptokinase-lys-plasminogen. ${ }^{12}$

In some patients, however, successful thrombolysis is not achieved. It has been suggested that high levels of resistance to streptokinase, probably acquired by previous exposure to streptococci, can compromise the therapeutic response to streptokinase.$^{1314}$ To overcome this, the "standard" dose of 1.5 MIU of streptokinase aims to achieve a lytic state in a high proportion of patients. A dose of $1.25 \mathrm{MIU}$ has been shown to achieve a lytic state in $97 \%$ of patients. ${ }^{15}$ Previous clinical studies, however, have not shown any relation between the pretreatment concentrations of IgG antibodies to streptokinase and efficacy as assessed by reperfusion rate or time to reperfusion with streptokinase or anistreplase. ${ }^{1617}$

Thrombolytic drugs containing streptokinase cause an antibody response that persists in the circulation for at least 4 years. ${ }^{1819}$ Although it has been suggested that high antibody concentrations are associated with a loss of efficacy ${ }^{1314}$ and a higher risk of anaphylactoid reactions, ${ }^{20}$ the evidence for this is inconclusive. In the light of the increasing use of streptokinase for acute myocardial infarction, and therefore the increasing likelihood of repeat administration of thrombolytic treatment, it is important that the role of these antibodies is better understood.

This study extends previous work by examining the relation between the streptokinase resistance titre and the concentration of specific IgG antibody to streptokinase, and the therapeutic response to the thrombolytic drugs containing streptokinase- - that is, streptokinase and anistreplase-assessed by coronary angiography. The streptokinase resistance titre is a measure of the total inhibitory capacity of the patient's plasma to streptokinase, and reflects not only the contribution of antibodies to streptokinase, but also the effects of circulating plasma inhibitors such as $\alpha_{2}$ antiplasmin and macroglobulins. It is influenced by changes in other plasma 
proteins such as fibrinogen and plasminogen, which show large changes after myocardial infarction and thrombolytic treatment. The concentration of IgG antibodies to streptokinase is a direct measure of the immune response, reflecting previous exposure to streptococcal protein, and is independent of circulating non-specific inhibitors.

\section{Patients and methods}

One hundred and twenty eight consecutive patients were recruited who had presented within six hours of the onset of symptoms of myocardial infarction. They had had chest pain for at least 30 minutes, and did not have any of the standard contraindications to thrombolytic treatment ${ }^{21}$ or coronary angiography; evaluable data were obtained in 124 patients. All patients had at least $1 \mathrm{~mm}$ of ST elevation in two limb leads, or at least $2 \mathrm{~mm}$ ST elevation in two precordial leads. Patients older than 70 years, or those who had had a previous myocardial infarction in the same anatomical distribution, or who had previously received thrombolytic treatment, were excluded. After discussion with the patient and attending relatives, written informed consent was obtained.

The mean (SD) age of our patients was $55 \cdot 6(8 \cdot 3)$ years, with a range of $31-70$ years.
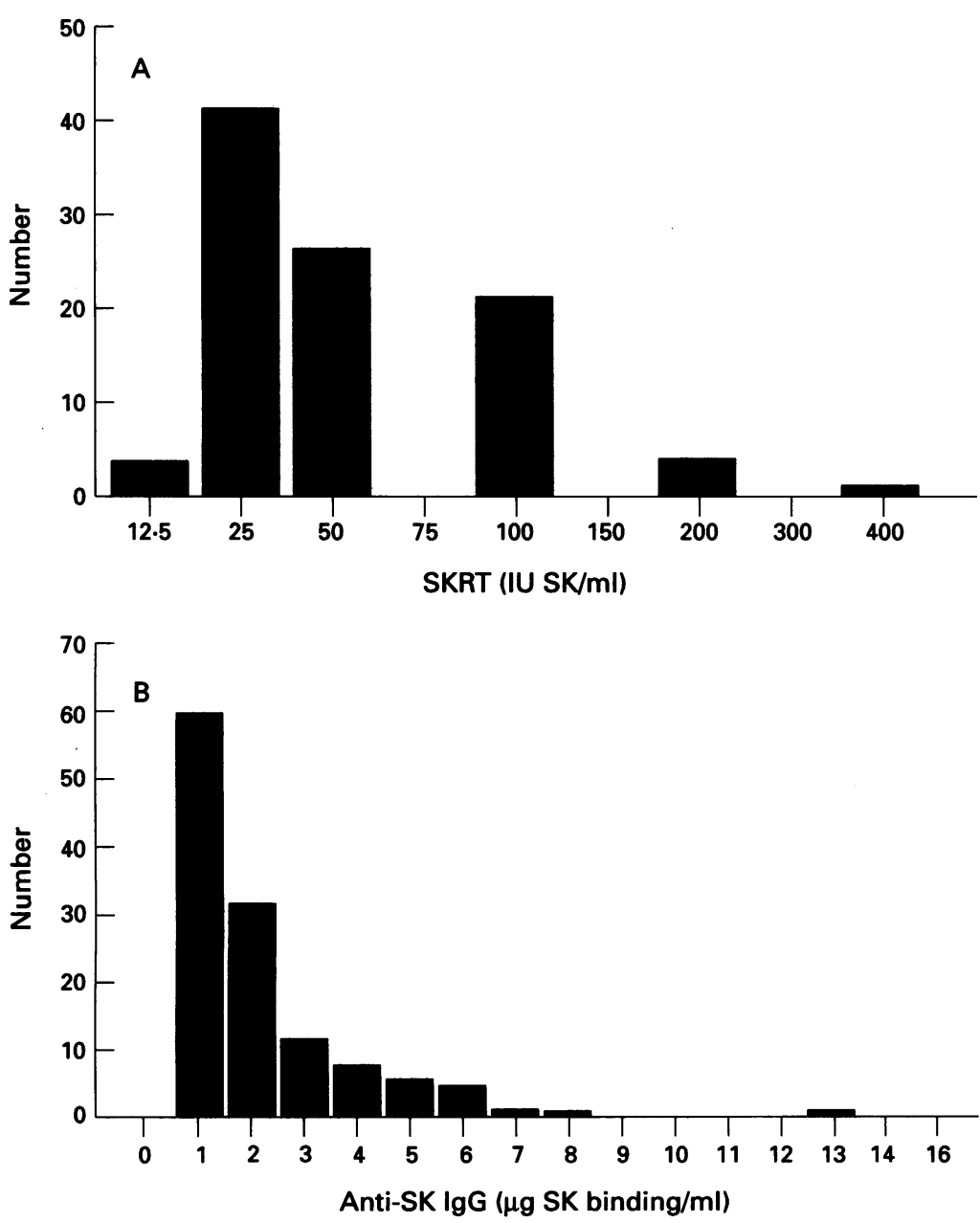

Frequency histograms of $(A)$ pretreatment streptokinase resistance titre (SKRT) and (B) concentrations of IgG antibodies to streptokinase (SK).
The mean (SD) time from onset of symptoms to the start of thrombolytic treatment was 204 (79) minutes. There were 101 men and 27 women. Patients were treated with either 1.5 MIU streptokinase ( 60 patients) as a continuous intravenous infusion over 60 minutes or 30 units of anistreplase (64 patients) as a five minute intravenous injection in a double blind, randomised design using matching placebo "streptokinase"/“anistreplase" for each patient to maintain observer blinding. All patients received $2 \mathrm{mg} / \mathrm{h}$ isosorbide dinitrate as a continuous intravenous infusion for at least 30 minutes before the start of thrombolytic treatment.

Coronary angiography was performed from the femoral route by Judkins' method, at 90 minutes and $24(18-30)$ hours after treatment. The infarct related artery indicated by the admission electrocardiogram was injected first. Coronary perfusion was scored on the Thrombolysis in Myocardial Infarction (TIMI) scale $^{21}$ by an independent, experienced cardiologist, blinded to the study protocol.

Venous blood samples were collected before the administration of thrombolytic treatment. In 124 patients (60 streptokinase, 64 anistreplase) specific antibodies to streptokinase of the IgG class were assayed using a specific microradioimmunoassay which has been described previously. ${ }^{22}$ In 96 of these patients (48 streptokinase, 48 anistreplase) streptokinase resistance titres were measured by standard methods. ${ }^{23}$ The remaining 28 were not sampled owing to technical problems. The time to treatment and patency rates were similar in all sampling groups.

The data were analysed using non-parametric descriptive statistics and tests of location (Mann-Whitney), complying with the conventional level of significance $(P<0.05)$. Patency rates were compared by the $\chi^{2}$ test.

\section{Results}

In our study group neither streptokinase resistance titre nor concentrations of IgG antibodies to streptokinase were normally distributed, with marked skewing towards higher values (figure).

Details of the study group and coronary patency rates in the treatment groups have been published previously. ${ }^{24}$ In summary, the mean age in the two treatment groups was similar (55.8 (streptokinase) $v 55.3$ years) as was the time to treatment (209 (streptokinase) $v 199$ minutes). A patency rate of $53 \%$ at 90 minutes and $87.5 \%$ at 24 hours was achieved in the streptokinase group, and a patency of $55 \%$ and $81 \%$ respectively in the anistreplase group. There was no significant difference between the patency rates of the two treatment groups at either time point.

There was a significantly higher streptokinase resistance titre in those patients with an occluded artery (TIMI grades 0 and 1) at 24 hours (median $100 v 50$ streptokinase IU $\mathrm{ml}^{-1}, \mathrm{P}=0.02$; table 1 ). In addition, there were non-significant trends towards a higher 
Table 1 Median streptokinase resistance titre values (streptokinase IU $\mathrm{ml}^{-1}$ ) according to Thrombolysis in Myocardial Infarction (TIMI) grading

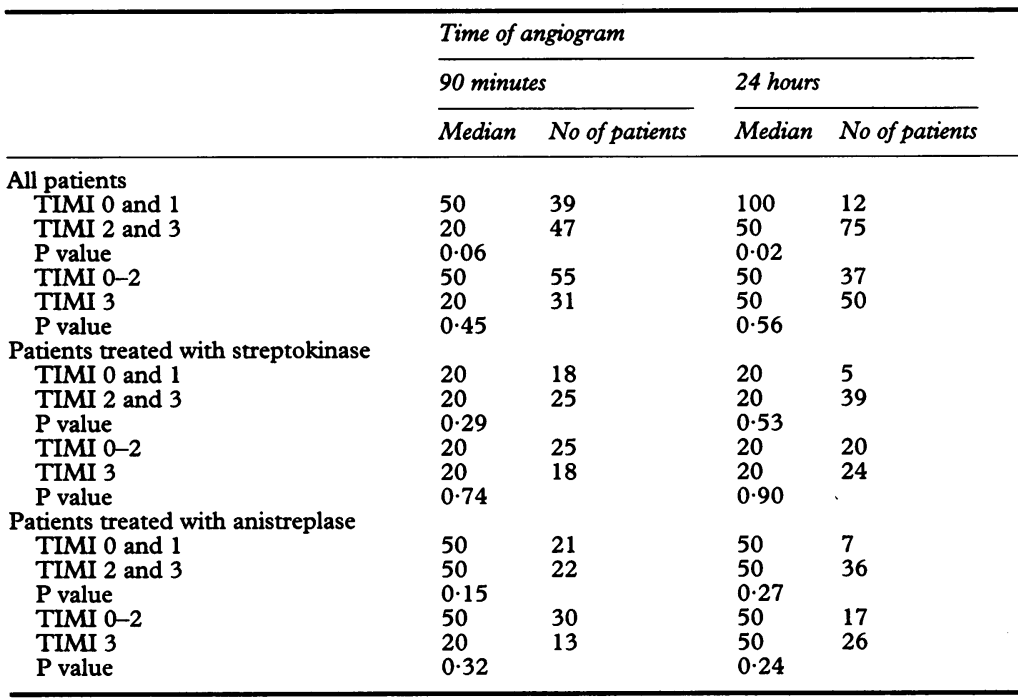

streptokinase resistance titre in those patients with an occluded index coronary artery at 90 minutes (median $50 v 20$ streptokinase IU $\mathrm{ml}^{-1}, \mathrm{P}=0.06$; table 1 ) and towards a higher concentration of IgG antibodies to streptokinase in those with an occluded artery at both 90 minutes and 24 hours, $(1.53 v 0.925, \mathrm{P}=$ $0.03 ; 1.65 v 1.04 \mu \mathrm{g}$ streptokinase binding $\mathrm{ml}^{-1}, \mathrm{P}=0.06$; table 2 ).

Analysis of the streptokinase and anistreplase treated groups separately showed consistent trends towards higher concentrations of IgG antibodies to streptokinase and minor trends towards a higher streptokinase resistance titre in those patients with persistent coronary occlusion.

Further analysis of TIMI grade 3 compared with TIMI grades $0-2$ at the two time points, as suggested by other studies, ${ }^{25}$ showed similar trends towards a higher streptokinase resistance titre and concentrations of IgG antibodies to streptokinase in those patients

Table 2 Median concentrations of IgG antibodies to streptokinase ( $\mu g$ streptokinase binding $\mathrm{ml}^{-1}$ ) according to Thrombolysis in Myocardial Infarction (TIMI) grading

\begin{tabular}{|c|c|c|c|c|}
\hline & \multicolumn{4}{|c|}{ Time of angiogram } \\
\hline & \multicolumn{2}{|c|}{90 minutes. } & \multicolumn{2}{|l|}{24 hours } \\
\hline & Median & No of patients & Median & No of patients \\
\hline \multicolumn{5}{|l|}{ All patients } \\
\hline TIMI 0 and 1 & 1.53 & 50 & 1.65 & 16 \\
\hline TIMI 2 and 3 & 0.925 & 62 & $1 \cdot 040$ & 96 \\
\hline $\begin{array}{l}\text { P value } \\
\text { TIMI 0-2 }\end{array}$ & 0.03 & & & \\
\hline $\begin{array}{l}\text { TIMI 0-2 } \\
\text { TIMI } 3\end{array}$ & $\begin{array}{l}1 \cdot 245 \\
0.985\end{array}$ & $\begin{array}{l}70 \\
42\end{array}$ & $\begin{array}{l}1.65 \\
0.92\end{array}$ & $\begin{array}{l}44 \\
68\end{array}$ \\
\hline P value & 0.23 & & 0.03 & \\
\hline \multicolumn{5}{|c|}{ Patients treated with streptokinase } \\
\hline TIMI 0 and 1 & $1 \cdot 84$ & 23 & 1.53 & 6 \\
\hline $\begin{array}{l}\text { TIMI } 2 \text { and } 3 \\
P \text { value }\end{array}$ & 0.92 & 31 & $1 \cdot 12$ & 48 \\
\hline $\begin{array}{l}\text { P value } \\
\text { TIMI 0-2 }\end{array}$ & 0.03 & & 0.62 & \\
\hline $\begin{array}{l}\text { TIMI 0-2 } \\
\text { TIMI } 3\end{array}$ & 1.49 & 31 & 1.57 & 23 \\
\hline $\begin{array}{l}\text { TIMI } 3 \\
\text { P value }\end{array}$ & 1.07 & 23 & 0.92 & 31 \\
\hline $\begin{array}{l}\text { P value } \\
\text { Patients treated } \mathrm{w}\end{array}$ & 0.46 & & 0.50 & \\
\hline \multicolumn{5}{|c|}{ Patients treated with anistreplase } \\
\hline $\begin{array}{l}\text { TIMI } 0 \text { and } 1 \\
\text { TIMI } 2 \text { and } 3\end{array}$ & $\begin{array}{l}1 \cdot 14 \\
0.93\end{array}$ & $\begin{array}{l}27 \\
31\end{array}$ & $\begin{array}{l}1.85 \\
0.98\end{array}$ & $\begin{array}{l}10 \\
48\end{array}$ \\
\hline $\begin{array}{l}\text { TIMI } 2 \text { and } 3 \\
\text { P value }\end{array}$ & $\begin{array}{l}0.93 \\
0.36\end{array}$ & 31 & 0.03 & 40 \\
\hline TIMI 0-2 & 1.06 & 39 & $1 \cdot 70$ & 21 \\
\hline TIMI 3 & 0.91 & 19 & 0.91 & 37 \\
\hline$P$ value & $0 \cdot 29$ & & 0.02 & \\
\hline
\end{tabular}

with less complete perfusion. These trends achieved conventional levels of significance when concentrations of IgG antibodies to streptokinase were compared in those patients with TIMI grades $0-2$ and TIMI grade 3 perfusion at 24 hours $(1.65 v 0.92, \mathrm{P}=0.03)$.

\section{Discussion}

The exact prevalence of antibodies to streptococcal protein and resistance to streptokinase in the community remains largely undefined. It has been suggested ${ }^{1314}$ that high levels of resistance to streptokinase may negate the efficacy of streptokinase administered to establish a lytic state for the treatment of disorders such as myocardial infarction. With increasing administration, and possible repeat administration, of thrombolytic treatment for this indication, it is important to define the relevance of resistance to thrombolytic drugs containing streptokinase.

The most commonly prescribed thrombolytic drug in the United Kingdom is streptokinase, and therapeutic administration of this drug and anistreplase is known to stimulate the development of antibodies to the streptokinase moiety, ${ }^{1826}$ which to date have been shown to persist in the circulation for at least 4 years. ${ }^{19}$ The relevance of this response remains undefined.

In this study we examined the influence of IgG antibodies to streptokinase and the functionally based assay of streptokinase resistance titres on the ability of thrombolytic drugs containing streptokinase to achieve coronary patency after acute myocardial infarction, a potential marker for mortality. ${ }^{25}$ The streptokinase resistance titre is a well established functional assay used to assess global in vivo resistance to streptokinase. The specific assay for IgG antibodies to streptokinase is relatively new, and the exact relevance of this antibody to the mechanism of acquired resistance to streptokinase remains to be established. It is expected that it is a reliable marker of previous exposure to streptococcal protein

There is a wide range of values of streptokinase resistance titre and concentrations of IgG antibodies to streptokinase in this study group presenting with acute myocardial infarction, who have not previously been exposed to drugs containing streptokinase. The distribution of these variables is markedly skewed, with most of this group having a low resistance to streptokinase. Data collected on this same group show that the median streptokinase resistance titre 30 months after treatment with the thrombolytic drugs containing streptokinase is about twice that before treatment. ${ }^{18}$ Although it is difficult to extrapolate from these data to the clinical context of repeat administration of thrombolytic drugs containing streptokinase, concerns about lack of efficacy and the higher risk of anaphylactoid reactions preclude the reexposure of patients with recurrent myocardial infarction to second doses of these drugs on ethical grounds. Also such a study would be inherently flawed by difficulties in knowing 
the coronary anatomy before the second event.

Within the range of these measured variables, the streptokinase resistance titre has a small, but demonstrable, influence on the efficacy of the thrombolytic drugs containing streptokinase. There was a significantly higher streptokinase resistance titre in patients with TIMI grades 0 and 1 at 24 hours, and trends towards higher streptokinase resistance titres in the comparable group for TIMI grades 0 and 1 at 90 minutes. There were also trends towards higher concentrations of IgG antibodies to streptokinase in these groups.

The differences are relatively minor and consistent with some previous studies which concluded that the efficacy of these drugs is not substantially influenced by the concentration of IgG antibodies to streptokinase, ${ }^{16}{ }^{17}$ or, in a small study, by streptokinase resistance titre when intracoronary streptokinase was given. ${ }^{27}$ Increased streptokinase resistance after streptokinase administration has been shown in the absence of an increase in the concentration of IgG antibodies to streptokinase. ${ }^{28}$

In the light of the Global Utilization of Streptokinase and t-PA for Occluded Arteries (GUSTO) study, ${ }^{25}$ which suggested that TIMI grade 3 perfusion was a better marker for survival, we analysed the data by comparing TIMI grade 3 with TIMI grades $0-2$. There were consistent trends towards those patients with TIMI grade 3 patency having lower pretreatment values of streptokinase resistance titre and concentrations of IgG antibodies to streptokinase, but statistical significance was only achieved in one subgroup. This may reflect the small sample sizes of the groups.

In the absence of an unequivocal effect of the concentration of IgG antibodies to streptokinase on efficacy, the role of other classes of immunoglobulin antibodies to streptokinase and non-specific inhibitors contributing to the streptokinase resistance titre requires further investigation. It remains important to document the influence of higher levels of resistance which are found after previous treatment with streptokinase, and the time course of these immunological reactions. Such studies may allow the development of flexible dosing regimens of thrombolytic drugs aimed at saturating the patient's resistance to streptokinase or may justify the use of non-immunogenic thrombolytic drugs.

We thank Dr R Fears of Beecham Pharmaceuticals for the measurement of streptokinase resistance titres and anti-SK IgG concentrations, and for discussion of the text. We also thank Dr I Hutton for reviewing the coronary angiograms, and Mrs J Clark for preparation of the text.

1 Anderson JL, Marshall HW, Askins JC, et al. A randomised trial of intravenous and intracoronary streptokinase in patients with acute myocardial infarction. Circulation 1984;70:606-18.

2 Kennedy JW, Gensini GG, Timmis GC, Maynard C. Acute myocardial infarction treated with intracoronary streptokinase: a report for the Society for Cardiac Angiography. Am $\mathcal{f}$ Cardiol 1985;55:871-7.

3 Been M, de Bono DP, Muir AL, et al. Clinical effects and kinetic properties of intravenous anistreplase-anisoylated plasminogen-streptokinase activator complex (BRI 26921 ) in acute myocardial infarction. Int $\mathcal{f}$ Cardio 1986;11:53-61.

4 ISAM Study Group. A prospective trial of intravenous streptokinase in acute myocardial infarction (ISAM). Mortality, morbidity and infarct size at 21 days. $N$ Engl $\mathcal{F}$ Mortality, morbidity and

5 Bassand J-P, Machecourt J, Cassagnes J, et al. Multicenter trial of intravenous anisoylated plasminogen streptokinase activator complex in acute myocardial infarction effects on infarct size and left ventricular function. $\mathcal{F} \mathrm{Am}$ Coll Cardiol 1989;13:988-97.

6 GISSI: Gruppo Italiano per lo Studio della Streptochinas nell'infarto Miocardio. Effectiveness of intravenous thrombolytic treatment in acute myocardial infarction. Lancet 1986;i:397-401.

7 AIMS Trial Study Group. Effect of intravenous anistreplase on mortality after acute myocardial infarction: preliminary report of a placebo-controlled clinical trial. Lancet 1988;i:545-9.

8 ISIS-3 (Third International Study of Infarct Survival) Collaborative Group. ISIS-3: a randomised comparison of streptokinase vs tissue plasminogen activator vs anistreplase and of aspirin plus heparin vs aspirin alone anistreplase and of aspirin plus heparin vs aspirin alone among 41299 cases of suspected

9 Gruppo Italiano per lo Studio della Soppravvivenza nell 'infarto Miocardico (GISSI). GISSI-2: A factorial ran domised trial of alteplase versus streptokinase an heparin versus no heparin among 12490 patients with acute myocardial infarction. Lancet 1990;336:65-71.

10 GREAT Group. Feasibility, safety, and efficacy of domiciliary thrombolysis by general practitioners: Grampian region early anistreplase trial. BMF 1992;305:548-53.

11 Anderson JL, Boissel JP, Chamberlain DA. Symposium on anisoylated plasminogen streptokinase activator complex (anistreplase). Drugs 1987;33 (suppl 3):31-2.

12 Ferres $\mathrm{H}$, Hibbs M, Smith RAG. Deacylation studies in vitro on anisoylated plasminogen streptokinase activator complex. Drugs 1987;33 (suppl 3):80-2.

13 Hirsh J, O'Sullivan EF, Martin M. Evaluation of a standard dosage schedule of streptokinase. Blood 1970 35:341-9

14 Lew AS, Neer T, Rodriguez L, Geft IL, Shah PK, Ganz W. Clinical failure of streptokinase due to an unsuspected high titer of antistreptokinase antibody. $\mathcal{F} \mathrm{Am}$ Coll Cardiol 1984;4:183-5.

15 Verstraete $M$, Vermylen J, Amery A, Vermylen C. Thrombolytic therapy with streptokinase using standard dosage scheme. $B M \mathcal{F}$ 1966;1:454-6.

16 Hoffmann JML, Fears R, Bonnier JJRM, Standring R, Ferres $H$, de Swart JBRM. Significance of antibodies to streptokinase in coronary thrombolytic therapy with streptokinase in coronary thrombolytic therapy with
streptokinase or APSAC. Fibrinolysis 1988;2:203-10.

17 Fears R, Hearn J, Standring R, Anderson JL, Marder VJ. Lack of influence of pretreatment antistreptokinase antibody on efficacy in a multicenter patency comparison of body on efficacy in a multicenter patency comparison of intravenous streptokinase and anistreplase in ac

18 Fears R, Ferres H, Glasgow E, et al. Monitoring of streptokinase resistance titre in acute myocardial infarction up to 30 months after giving streptokinase or anistreplase and related studies to measure specific antistreptokinase IgG. Br Heart $₹$ 1992;68:167-70.

19 Lee HS, Cross S, Davidson R, Reid T, Jennings K. Raised levels of antistreptokinase antibody and neutralization titres from 4 days to 54 months after administration of streptokinase or anistreplase. Eur Heart $f$ 1993;14:84-9.

20 Dykewicz MS, McGrath KG, Davison R, Kaplan KJ, Patterson R. Identification of patients at risk for anaphy-
laxis due to streptokinase. Arch Intern Med 1986;146: laxis due 7 .

21 TIMI Study Group. The thrombolysis in myocardial infarction (TIMI) trial. Phase I findings. $N$ Engl $f$ Med 1985;312:932-6.

22 Moran DM, Standring R, Lavender EA, Harris GS. Assessment of anti-streptokinase antibody levels in human sera using a microradioimmunoassay procedure. Thromb Haemost 1985;52:281-7.

23 Deutsch E, Fischer M. Die Wirkung intravenos applizierter Streptokinase auf Fibrinolyse und
Blutgerinnung. Thromb Diath Haemorrh 1960;4: 482-506.

24 Hogg KJ, Gemmill JD, Burns JMA, et al. Angiographic patency study of anistreplase versus streptokinase in patency study of anistreplase versus streptokinase

25 The GUSTO Investigators. An international randomized trial comparing four thrombolytic strategies for acute trial comparing four thrombolytic strategies for acute

26 Jalihal S, Morris GK. Antistreptokinase titres after intravenous streptokinase. Lancet 1990;335:184-5.

27 Rothbard RL, Fitzpatrick PG, Francis CW, Caton DM, Hood WB, Marder VJ. Relationship of the lytic state successful reperfusion with standard- and low-dose intracoronary streptokinase. Circulation 1985;71:562-70.

28 Buchalter MB, Suntharalingam G, Jennings I, et al. Streptokinase resistance: when might streptokinase administration be ineffective? $\mathrm{Br}$ Heart $\mathcal{f}$ 1992;68: 449-53. 